\title{
Kedekatan Remaja Pada Ibu: Pendekatan Indigenous Psychology
}

\author{
Tantio Fernando, Diana Elfida
}

\author{
Universitas Islam Negeri Sultan Syarif Kasim Riau \\ email: tantiofernando@ymail.com
}

\begin{abstract}
Abstrak
Seorang ibu memiliki kesempatan yang lebih besar untuk membangun hubungan yang dekat dengan anak-anaknya. Budaya memainkan peran penting dalam menentukan kedekatan tersebut. Penelitian ini bertujuan untuk mengungkap kedekatan remaja dan ibu dalam konteks masyarakat di Provinsi Riau. Dengan pendekatan Indigenous Psychology, responden ( $N=686$ orang) menjawab pertanyaan "Seberapa dekat yang Anda rasakan dengan ibu Anda?" dan "Apa yang membuat Anda dekat dengan Ibu Anda?" Pengkodean dan pengkategorian terhadap jawaban responden dilakukan tim peneliti dari Center for Indigenous \& Cultural Psychology Fakultas Psikologi UIN Sultan Syarif Kasim Riau. Data hasil kategorisasi dianalisis dengan menggunakan tabulasi silang secara umum. Hasil analisis data menunjukan bahwa sebagian besar partisipan $(96,8 \%)$ merasa sangat dekat dengan ibu. Ditemukan perbedaan alasan kedekatan dengan ibu antara laki-laki dan perempuan pada faktor ikatan emosional bahwa perempuan lebih dekat dengan ibu dikarenakan keterbukanya sedangkan lakilaki dikarenakan adanya afeksi positif yang didapatkandari ibu. Terdapat enam faktor yang menjadi alasan kedekatan dengan ibu, yaitu ikatan emosional $(73,6 \%$ dari seluruh partisipan), peran ibu $(11,2 \%)$, respek $(5,8 \%)$, dukungan $(3,4 \%)$, pertalian darah $(3,2 \%)$, dan ibu sebagai figur $(2,8 \%)$. Hasil penelitian ini berimplikasi pada program pemberdayaan keluarga, khususnya pada bagaimana ibu mempraktekan pengasuhan yang positif untuk membangun kedekatan dengan anak-anaknya, baik laki-laki maupun perempuan.
\end{abstract}

Kata kunci: kedekatan, remaja, ibu, ikatan emosional

\section{Adolescent closeness in Mother: Approach Indigenous Psychology}

\begin{abstract}
Mother has more opportunities to build close relationship with her children. It is culture that plays significant role in how closeness develops between them. This research was aimed to explore adolescent's closeness with mother in Riau Province. Using indigenous psychology, 686 adolescents were asked to answer a questionnaire consisted two questions, "How close do you feel with your mother?" and "What make you close to your mother?. Coding and categorization of the answers were conducted by researchers team from Center for Indigenous \& Cultural Psychology of Faculty of Psychology, UIN Sultan Syarif Kasim Riau. Cross tabulation was used to analyze the data. The result showed that most of participants $(96,8 \%)$ felt very close with their mothers. We found six factors determined the closeness, namely emotional bond $(73,6 \%$ of all participants), the role of a mother $(11,2 \%)$, respect $(5,8 \%)$, support $(3,4 \%)$, cognation $(3,2 \%)$, and mother as a figure $(2,8 \%)$. Furthermore, boys differed from girls in emotional bond with mother. Boys' emotional bonds was due to positive affection from mothers, while girls' was because of openness with their mothers. This research has implication on family empowerment program, especially how mothers practice positive parenting in order to build closeness with their children, both girls and boys.
\end{abstract}

Key words: closeness, adolescent, mother, emotional bond

\section{Pendahuluan}

Remaja merupakan masa dimana setiap individu membutuhkan dukungan dan perhatian yang lebih dari orang di sekitar guna membantu remaja menghadapi tugas perkembangannya. Orang di sekitar yang paling berperan ialah orangtua. Santrock (1998) mengungkapkan bahwa kedekatan remaja dan orangtua juga mampu menunjang pembentukan kompetensi sosial dan keberadaan remaja secara umum, serta mempengaruhi harga diri, kematangan emosi, dan kesehatan secara fisik. Lestari (2013) menjelaskan kedekatan merupakan aspek spesifik dari kehangatan yang mencakupi keintiman, afeksi 
positif, dan pengungkapan diri.

Dalam kedekatan antara orang tua dan anak, diketahui bahwa ibu memiliki peluang untuk menciptakan kedekatan dengan remaja lebih intens dibandingkan ayah. Hal ini dijelaskan oleh Sputa dan Paulson (dalam Santrock, 2007) yang mengungkapkan bahwa ibu memiliki keterlibatan yang lebin besar dalam pengasuhan dibanding ayah. Ibu lebih berkesempatan menciptakan komunikasi dan keterbukaan serta kebersamaaan yang diduga akan meningkatkan kedekatan antara remaja dan orangtua dan keluarga pada umumnya. Hal serupa juga disampaikan oleh Barnes dan Olson (1985) yang juga menyatakan bahwa ibu menunjukkan komunikasi yang lebih baik dengan anak dibanding ayah.

Kedekatan ibu dalam berbagai studi dijelaskan sebagai perawat (Setiono, 2011), komunikator yang baik (Barnes \& Olson, 1985), mengerti dan memberikan kenyamanan (Park \& Kim, 2006), dan berorientasi percakapan (Noh \& Yusuff, 2011). Studi yang dilakukan oleh Raudatussalamah, Chairani, Fitri, dan Hidayat (2012) pada budaya Melayu Riau, menemukan bahwa kepercayaan remaja pada ibu sangat tinggi.

Peran dan sosok ibu di negara timur yang berbudaya kolektif, khususnya pada budaya Melayu, cenderung lebih ditekankan untuk menciptakan lingkungan yang dekat. In- dividu tidak selalu dituntut untuk mandiri dan otonom, lebih tepatnya terdapat penekanan mengenai hubungan yang saling ketergantungan (Markus dan Kitayama, 1991). Berbeda dengan barat, yang bersifat individualis, menekankan keunikan individu, keterpisahan, dan keabstrakan identitas yang menyatakan bahwa individu itu unik (Park \& Kim, 2006).

\section{Relasi Orangtua-Anak}

Orangtua berperan sebagai tokoh kelekatan dan sistem pendukung yang penting ketika remaja mulai melakukan eksplorasi dalam dunia sosial yang lebih luas dan kompleks dengan lingkungan di sekitarnya (Santrock, 2011). Orangtua bertanggungjawab terhadap perawatan, pendidikan dan kesejaheraan umum anak-anaknya. Steriotipe yang berlaku pada umumnya ialah bahwa ibu diasosiasikan sebagai perawat dan ayah berperan dalam interaksi bermain (Setiono, 2011).

Seorang ibu merupakan dunia batin penerimaan dan kepuasan dan ayah mewakili dunia luar yang ketat, aturan, dan tanggung jawab (Park \& Kim, 2006). Sementara sang ayah merupakan dunia luar, ibu merupakan bagian dalam dunia keluarga dan bertanggung jawab untuk menjaga keharmonisan dalam hubungan interpersonal (Hwang, 2006).

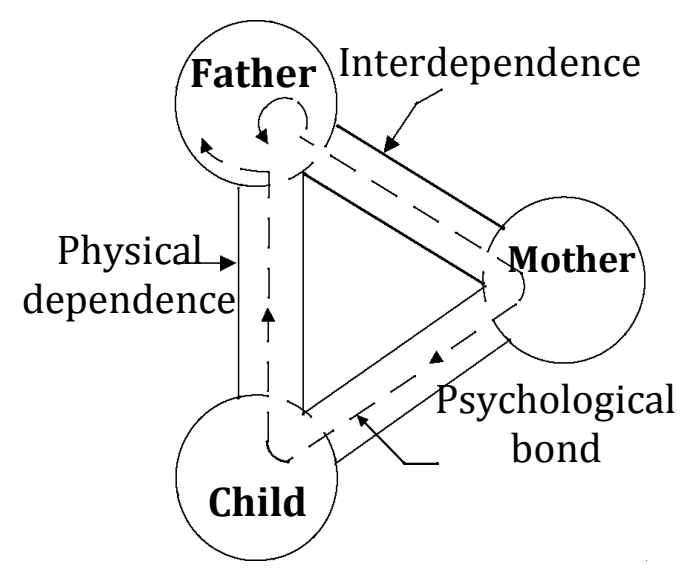

Gambar 1. Triadic Relationship

(Park \& Kim, 2006 hal. 426) 
Kedekatan Ibu dan Anak

Kedekatan orangtua dan anak terbentuk melalui kebersamaan berbagi cerita (keterbukaan). yang menyatakan ibu menunjukkan komunikasi yang lebih baik dengan anak dibanding ayah (Lestari 2013; Barnes \& Olson,1985) Studi lanjut dilakukan oleh Park dan Han (dalam Park \& Kim, 2006) ketika remaja ditanya alasan mengapa dekat dengan ibu, mereka menjawab dikarenakan ibu adalah figur yang mengerti $(27 \%)$ nyaman $(22 \%)$ kekerabatan $(17 \%)$ dan sisanya disebabkan oleh faktor lain.

Kedekatan menjadi faktor penentu hubungan baik antara orang tua dan anak yang berperan penting bagi perkembangan pada masa remaja. Sebagai model yang akan dibawa seumur hidup dan mempengaruhi terbentuknya relasi-relasi baru bagi remaja dikemudian hari (Driscoll \& Pianta 2011; Hurlock, 1998). Pada remaja, kedekatan dengan orangtua menjadi prediktor bagi kesuksesan masa perkembangan remaja. Remaja yang tidak dekat dan atau tidak bersama orangtua minimal 5 kali sehari perminggu beresiko mengembangkan permasalahan tingkah laku dan pelanggaran hukum, seperti merokok, konsumsi alkohol, menggunakan marijuana, perkelahian dan aktivitas seksual beresiko (Santrock, 2011).

Rodgers (dalam Lestari, 2013) lebih lanjut menjelaskan apabila tingkat kedekatan orangtua dengan anak rendah, maka remaja cenderung mempersepsikan pemantauan yang dilakukan oleh orangtua sebagai gangguan, sehingga kedekatan orangtua dengan remaja akan berbanding terbalik dengan tingkat konflik orangtua dan anak serta masalah remaja di lingkungan sosialnya. Demikian juga bila ada rasa saling percaya antara anak dan orangtua, maka pemantauan yang dilakukan orangtua dimaknai sebagai bentuk perhatian dan akan mendukung semakin terciptanya kedekatan yang lebih baik (Ihromi, 1999; Shek, dalam Lestari, 2013).

Secara khusus Park dan Kim (2006) menjelaskan bagaimana kedekatan ibu dengan anak dibentuk dan berkembang. Peran ibu dimulai semenjak anak berada dalam kandungan. Ibu diajarkan untuk berpikir, mer- asa, dan bertindak demi bayi dalam kandungannya. Ibu bertanggung jawab untuk membesarkan anak-anak, memastikan bahwa anak-anak menghormati dan mematuhi ayah mereka, merawat orangtua dan anggota keluarga, dan mengelola urusan rumah tangga. Ibu mensosialisasikan dan mengajarkan antara anak laki-laki dan perempuan dengan cara yang berbeda. Anak laki-laki diajarkan untuk menjadi pemimpin dan untuk menjadi pencari nafkah dan perempuan diajarkan untuk mengikuti dan mendukung calon suaminya dan keluarga.

Sebagai remaja, anak merasakan bahwa melalui ibu mereka mendapatkan kepuasan, keamanan, dan cinta, sehingga anak menjadi termotivasi untuk mempertahankan hubungan yang dekat dengan ibu mereka. Remaja melakukannya secara bertahap dan mengambil peran yang lebih aktif dengan mencoba untuk menyenang-kan ibu mereka, berperilaku sesuai dengan keinginan ibu serta menginternalisasikan nilai-nilai dan keyakinan ibu kedalam dirinya (Hwang, 2006). Melalui ikatan emosional yang kuat ini ibu mendorong anak untuk berinteraksi dengan orang lain, seperti ayah, saudara dan guru (Kim dalam Park \& Kim, 2006).

Pada budaya kolektif (Korea) ibu memandang pengabdian dan pengorbanan sebagai bentuk peran dan tugas yang mendasar. Kim, Park dan Choi (dalam Hwang, 2006) mengatakan, bagi banyak wanita, ibu merupakan peran yang paling penting. Figur diri seorang ibu tidak akan hilang dari anaknya, ibu akan tertanam dalam diri anak tersebut dan menjadi satu dengan anak-anaknya. Park dan Kim (2006) memaparkan bahwa, tujuan kehidupan ibu ialah agar dapat berhubungan erat dan lekat (intrinsik) dengan anak-anaknya.

Dalam budaya Indonesia, pemberian perawatan dari ibu kepada anak selalu mempertimbangkan tiga prinsip pengasuhan anak, yaitu asih (kasih sayang) asah (merangsang potensi) dan asuh (memenuhi kebutuhan) (Hakim dkk, 2012). Kedekatan yang terbentuk dengan remaja merupakan bentuk keberhasilan peran orangtua (ayah dan ibu). Lestari (2013) mengungkapkan bahwa kedekatan 
remaja dicirikan dengan berbagi cerita dengan ayah dan ibu tentang peristiwa yang dialami di sekolah dan melakukan kegiatan bersama seperti menonton televisi, melakukan tugas rumah, dan berekreasi. Peran antara ayah dan ibu sangat berbeda, namun saling melengkapi dalam peran yang terbaik (Park \& Kim, 2006). Kedekatan merupakan aspek spesifik dari kehangatan yang mencakup keintiman, afeksi positif, dan pengungkapan diri (keterbukaan) (Lestari, 2013).

Penelitian yang dilakukan Raudatussalamah, Chairani, Fitri, Hidayat (2012) pada remaja di kota Pekanbaru menemukan bahwa $76,7 \%$ remaja sangat percaya dengan ibu, $20,5 \%$ percaya dan $2,8 \%$ cukup percaya. Melalui tingkat kepercayaan ini remaja terhadap ibu turut mempengaruhi kedekatan anak terhadap ibu. Ini menunjukan bahwa bagi remaja Melayu ibu merupakan sosok yang sangat dipercayai dan yang paling berkesempatan berkomunikasi dan dekat dengan remaja. Ihromi menginggapkan bahwa dari kepercayan ini turut mendukung terciptanya kedekatan antara remaja dan ibu.

Uraian di atas menunjukkan perbedaan budaya turut berpengaruh tentang bagaimana peran ibu dalam terciptanya kedekatan antara remaja dan ibu. Ibu dalam budaya kolektif diasumsikan berkesempatan dan memiliki peluang untuk menciptakan kebersamaan serta komunikasi yang lebih intens dengan remaja. Hal ini diduga akan menciptakan kedekatan antara ibu dan remaja. Penelitian ini bertujuan untuk melihat kedekatan anak dan remaja dalam konteks budaya kolektif yang ada di Indonesia, khususnya yang berlatar belakang budaya Melayu di Provinsi Riau. Penelitian ini bermaksud untuk mengetahui seberapa dekat remaja dengan ibu, alasan apa saja yang menyebabkan remaja dekat dengan ibu serta apakah ada perbedaan yang menyebabkan remaja laki-laki dan perempuan dekat dengan ibu mereka di Provinsi Riau.

\section{Metode}

Metode yang digunakan ialah kuantitatif deskriptif dengan pendekatan indigenous psychology. Kim dan Berry (dalam Park \& Kim, 2006) menjelaskan indigenous psychology sebagai "the scientific study of human behavior or mind that is native, that is not transported from other regions, and that is designed for its people".

\section{Subjek}

Sebanyak 686 remaja $(L=263 ; P=423)$ yang berusia 11-22 tahun berpartisipasi dalam penelitian ini. Partisipan berasal dari 6 SMA/ sederajat di Pekanbaru, 1 SMK di Kabupaten Rokan Hulu, 1 SMK di Kabupaten Kuantan Singingi, 1 SMK di Kabupaten Kampar, dan mahasiswa sebuah perguruan tinggi negeri di Pekanbaru.

\section{Instrumen}

Instrument yang digunakan angket untuk mengumpulkan data, yang terdiri dari pertanyaan tertutup dan terbuka. Pertanyaan tertutup yaitu "Seberapa dekat anda dengan ibu Anda?" . Terdiri dari respon-respon yang dikodekan sebagai berikut: tidak dekat, kurang dekat, cukup dekat, dekat dan sangat dekat. Data kuantitatif dianalisis dengan menggunakan statistik deskriptif untuk menemukan tingkat kedekatan responden dengan ibu mereka. Pertanyaan terbuka yaitu "Apa yang membuat Anda dekat dengan Ibu Anda?". Analisis data kualitatif dilakukan dengan mengidentifikasi informasi spesifik, membagi dan merumusakan tema yang muncul. Pada akhirnya ditujukan untuk mengahasilkan data yang relevan mengenai alasan remaja dekat dengan ibu.

\section{Hasil}

\section{Deskripsi Data}

Bagian ini akan memaparkan jawaban responden terhadap dua pertanyaan angket. Tabel 1 memperlihatkan distribusi jawaban partisipan terhadap pertanyaan "Seberapa dekat anda dengan ibu?". Hasilnya menunjukkan bahwa sebagian besar remaja $(63,6 \%)$ merasa amat sangat dekat dengan ibu. Hanya sedikit yang mengaku agak dekat $(2,8 \%)$ dan kurang dekat dengan ibu $(0,4 \%)$. 
Tabel 1: Kedekatan Remaja Terhadap Ibu

\begin{tabular}{lllll}
\hline Kedekatan & $\mathrm{f}$ & $\%$ & Valid Persen & Kumulasi Persen \\
\hline Amat Sangat Dekat & 436 & $63.6 \%$ & 63.6 & 63.6 \\
Sangat Dekat & 228 & $33.2 \%$ & 33.2 & 96.8 \\
Agak Dekat & 19 & $2.8 \%$ & 2.8 & 99.6 \\
Kurang Dekat & 3 & $0.4 \%$ & 0.4 & 100.0 \\
Total & 686 & $100.0 \%$ & 100.0 & \\
\hline
\end{tabular}

Jawaban atas pertanyaan kedua, vasi dan bimbingan), pertalian darah dan figur "Apa yang membuat Anda dekat dengan Ibu (lihat Tabel 2). Ikatan emosional menjadi fakAnda?", menunjukkan ada 6 alasan kedeka- tor utama yang membuat remaja dekat dentan remaja dan ibu. Keenam faktor tersebut gan ibu, yang dijawab oleh 73,6\% partisipan. yaitu ikatan emosional (afek positif, keterbu- Lima faktor berikutnya secara berturut-turut kaan, kebersamaan, dan mengerti), peranan adalah peranan ibu $(11,2 \%)$, respek $(5,8 \%)$, ibu (pengasuhan dan pengorbanan), respek dukungan $(3,4 \%)$, pertalian darah $(3,2 \%)$, dan (segalanya dan berharga), dukungan (moti- figur $(2,8 \%)$.

Table 2. Alasan Remaja Dekat Dengan Ibu

\begin{tabular}{llll}
\hline Kategori & $\mathrm{f}$ & $\%$ & Valid \\
\hline 1. Ikatan Emosional & $\mathbf{5 0 5}$ & $\mathbf{7 3 , 6 \%}$ & \\
Afeksi positif & 192 & $28,0 \%$ & \\
Keterbukaan & 136 & $19,8 \%$ & $\mathbf{7 3 , 6}$ \\
Kebersamaan & 116 & $16,9 \%$ & \\
Mengerti & 61 & $8,9 \%$ & \\
2. Peranan ibu & $\mathbf{7 7}$ & $\mathbf{1 1 , 2} \%$ & \\
Pengasuhan & 41 & $6,0 \%$ & $\mathbf{1 1 , 2}$ \\
Pegorbanaan & 36 & $5,2 \%$ & \\
3. Respek & $\mathbf{4 0}$ & $\mathbf{5 , 8} \%$ & \\
Segalanya & 35 & 5,1 & $\mathbf{1 1 , 2}$ \\
Berharga & 5 & $0,7 \%$ & \\
4. Dukungan & $\mathbf{2 3}$ & $\mathbf{3 , 4} \%$ & \multirow{3}{*}{$\mathbf{2}$} \\
Motivasi & 14 & $2,0 \%$ & \\
Bimbingan & 9 & 1,3 & $\mathbf{3 , 2}$ \\
$\mathbf{5 . ~ P e r t a l i a n ~ d a r a h ~}$ & $\mathbf{2 2}$ & $\mathbf{3 , 2} \%$ & $\mathbf{2 , 8}$ \\
6. Figur & $\mathbf{1 9}$ & $\mathbf{2 , 8} \%$ & $\mathbf{1 0 0 , 0}$ \\
\hline Total & $\mathbf{6 8 6}$ & $\mathbf{1 0 0 , 0} \%$ & \\
\hline
\end{tabular}


Tabel 3: Kedekatan Remaja Pada Ibu Ditinjau Dari Jenis Kelamin.

\begin{tabular}{|c|c|c|c|}
\hline \multirow[t]{2}{*}{ Kategori } & \multicolumn{2}{|c|}{ Jenis Kelamin } & \multirow[t]{2}{*}{ Total } \\
\hline & Laki-laki & Perempuan & \\
\hline 1. Ikatan Emosional & $187(71,1 \%)$ & $318(75,2 \%)$ & 505 (73,6\%) \\
\hline Afeksi positif & $100(38,0 \%)$ & $92(21,7 \%)$ & $192(28,0 \%)$ \\
\hline Keterbukaan & $27(10,3 \%)$ & $109(25,8 \%)$ & $109(19,8 \%)$ \\
\hline Kebersamaan & $45(17,1 \%)$ & $71(16,8 \%)$ & $116(16,9 \%)$ \\
\hline Mengerti & $15(5,7 \%)$ & $46(10,9 \%)$ & $61(8,9 \%)$ \\
\hline 2. Peranan ibu & $42(16,0 \%)$ & $35(8,3 \%)$ & $77(11,2 \%)$ \\
\hline Pengasuhan & $25(9,5 \%)$ & $16(3,8 \%)$ & $41(6,0 \%)$ \\
\hline Pegorbanaan & $17(6,5 \%)$ & $19(4,5 \%)$ & $36(5,2 \%)$ \\
\hline 3. Respek & $13(4,9 \%)$ & $27(6,4 \%)$ & $40(5,8 \%)$ \\
\hline Segalanya & $12(4,6 \%)$ & $23(5,4 \%)$ & $35(5,1 \%)$ \\
\hline Berharga & $1(0,1 \%)$ & $4(0,9 \%)$ & $5(0,7 \%)$ \\
\hline 4. Dukungan & $10(3,8 \%)$ & $13(3,1 \%)$ & $23(3,4 \%)$ \\
\hline Motivasi & $4(1,5 \%)$ & $10(2,4 \%)$ & $14(2,0 \%)$ \\
\hline Bimbingan & $6(2,3 \%)$ & $3(0,7 \%)$ & $9(1,3 \%)$ \\
\hline 5. Pertalian darah & $8(3,0 \%)$ & $14(3,3 \%)$ & $22(3,2 \%)$ \\
\hline 6. Figur & $3(1,1 \%)$ & $16(3,8 \%)$ & $19(2,8 \%)$ \\
\hline Total & 263 (100\%) & $423(100 \%)$ & $686(100,0 \%)$ \\
\hline
\end{tabular}

Pada table 3 menunjukkan baik lakilaki maupun perempuan alasan kedekatan dengan ibu adalah karena faktor ikatan emosional. Meskipun demikian, persentasi remaja perempuan yang dekat karena alasan emosional lebih tinggi daripada laki-laki (masingmasing $75,2 \%$ dan $71,1 \%$ ). Sementara, remaja laki-laki yang merasa dekat dengan ibu karena faktor peranan ibu sebanyak $16,0 \%$, lebih banyak daripada remaja perempuan $(8,3 \%)$. Hal yang menarik adalah ikatan emosional berupa afeksi positif lebih banyak dirasakan remaja laki-laki $(38,0 \%)$ daripada remaja perempuan $(21,7 \%)$.

\section{Hasil Focus grup discussion (FGD)}

FGD dilakukan untuk menemukan alasan-alasan remaja tersebut guna mengetahui mengapa hal tersebut dapat terjadi. FGD dilakukan sebanyak 3 sesi, pada sesi pertama melibatkan 6 subjek, sesi kedua melibatkan 8 subjek, dan pada sesi ketiga melibatkan 6 subjek penelitian.

\section{Ikatan Emosional}

Ikatan merupakan konsep yang mengacu pada hubungan yang intens, baik secara fisik maupun emosi yang saling mengikat erat antara remaja dengan ibunya. FGD ini melihat ikatan emosional yang lebih dirasakan remaja laki-laki berupa afeksi positif dan perempuan berupa keterbukaan. Afeksi positif mengacu pada konsep kasih sayang, cinta dan perasaan yang ibu berikan melalui emosi positif, kepedulian dan perhatian, sehingga anak merasakan perasaan aman dan dan nyaman dengan ibunya. Keterbukaan merupakan bentuk ikatan emosional yang tercipta melalui komunikasi yang efektif. Dalam keluarga dibutuhkan komunikasi yang intens antara remaja dan ibu sebagai bentuk keterlibatan, berupa kepedulian ibu terhadap kegiatan yang dilakukan oleh remaja.

\section{Peranan ibu}

Peranan ibu yang dimaksud meliputi pengasuhan dan pengorbanan yang ibu lakukan. Pengasuhan meliputi membesarkan, mengurus, merawat, membantu, mengajari, memberi pertolongan, memenuhi kebutuhan serta mengajarkan pendidikan, nilai dan etika. Focus grup discussion menemukan bahwa yang termasuk pengasuhan dalam peranan ibu ialah pemenuhan kebutuhan serta memberikan hak wajib anak baik yang dibutuhkan sekarang maupun yang akan bermanfaat dikemudian hari. Pengorbaan yang dimakud meliputi segala hal yang berkaitan dengan mementingkan kepentingan anaknya diatas kepentingan dirinya sendiri. 
Respek (Rasa Hormat)

Respek yang dimaksud dalam bentuk pemaknaan yang di berikan anak terhadap ibu sebagai bentuk rasa terima kasih dan rasa hormat. Respek timbul melalui ikatan yang kuat antara remaja dan ibunya sebagai bentuk penghargaan atas segala hal yang telah ibu lakukan. Respek merupakan bentuk penghargaan terhadap keterlibatan ibu dalam dukungan, peranan ibu dan ikatan emosional serta segala hal yang ibu lakukan yang menciptakan kebermaknaan positif bagi remaja.

\section{Dukungan}

Dukungan orangtua menjadikan remaja merasa dihargai, dipedulikan, dan berarti. Hal ini menimbulkan rasa semangat dan dapat menghadapi berbagai macam masalah serta menemukan solusi, sehingga remaja memiliki semacam keterkaitan ikatan antara mereka dan ibunya, menganggap ibu sebagai pahlawan, penyelamat yang ada dan membantunya dalam kondisi apapun.

\section{Pertalian darah}

Pertalian darah merupakan hubungan yang dilandasi ikatan darah atau ketu- runan yang mengikat antara remaja dan ibu. Hubungan ini terjalin secara langsung ketika seorang anak sudah berada didalam kandung kemudian dilahirkan oleh ibunya. Remaja menjelaskan bahwa tidak akan mempengaruhi kedekatan mereka dengan ibu jika mereka mengetahui bahwa ibu mereka bukan ibu kandung mereka.

Figur

Orangtua merupakan sosok yang paling pertama diteladani dan dimodel oleh anaknya. Didalamnya mereka belajar, berinteraksi, berkomunikasi dan memahami nilainilai dan norma-norma sehingga seorang anak menggunakan model yang pertama kali dipahami dan dapat dipercaya ini sebagai model atau figur yang digunakan di kemudian hari di lingkungan sekitarnya.

\section{Dinamika Kedekatan Remaja dengan Ibu}

Berdasarkan konsep-konsep yang ada dan melalui respon jawaban subjek, wawancara indeep, FGD (Focus Grup Discussion) pada subjek dan diskusi oleh seluruh peneliti Indigenous psychology maka ditemukan dinamika kedekatan anak dan remaja.

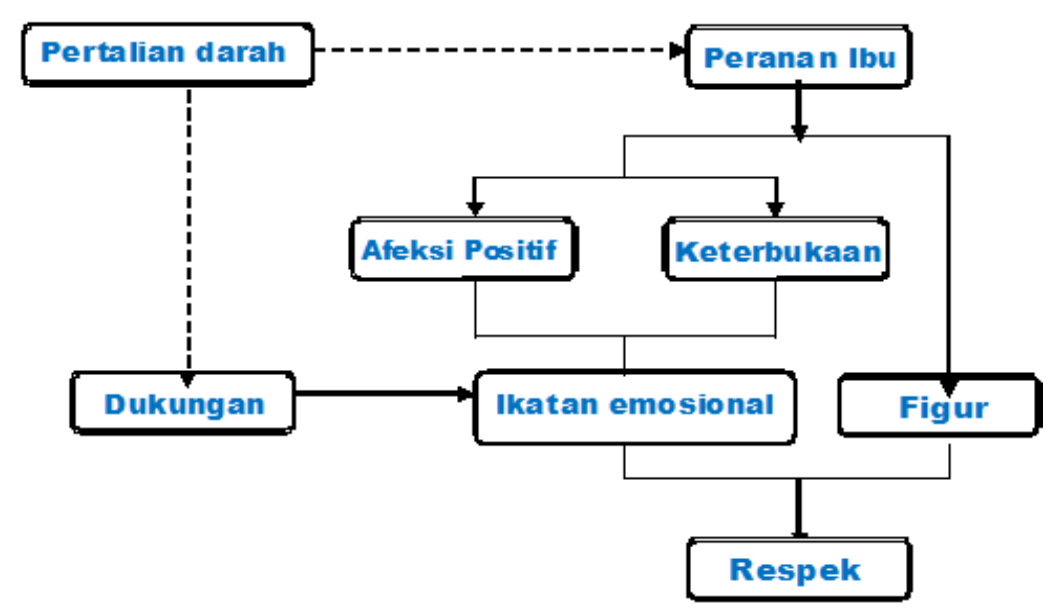

Gambar 2: Dinamika Kedekatan Remaja dan Ibu

Gambar 2 menjelaskan bahwa pada dasarnya kedekatan remaja dengan ibu tercipta melalui pertalian darah antara orangtua dan remaja. Namun tidak menutup kemungkinan bahwa tanpa ada pertalian darah, seorang anak akan tetap dekat dengan ibu yang selama ini telah merawatmya. Melalui hubun- gan antara remaja dan ibu akan membentuk keterlibatan berupa peranan ibu (mothering). Seiring dengan berjalannya perkembangan anak maka melalui peranan ini remaja akan mendapatkan afeksi positif sebagai bentuk kasih sayang yang berasal dari ibu (personal) dan keterbukaan sebagai bentuk relasi dalam 
komunikasi yang positif antara remaja dan ibu serta figur atau panutan yang dapat diteladani. Hadirnya peranan ibu secara bersamaan juga akan mampu menciptakan dukungan guna membantu anak, baik secara moril maupun materil.

Dukungan, afeksi positif, dan komunikasi akan membentuk ikatan secara emosional sebagai bentuk rasa cinta, perhatian, kepedulian dan kasih guna menciptakan kedekatan secara emosional antara remaja dengan ibu. Melalui ikatan emosional dan figur, remaja merasa bahwa segala yang telah ibu lakukan membuat ibunya menjadi begitu berarti yang selanjutnya menciptakan respek (rasa hormat) terhadap ibunya. Efeknya adalah kedekatan antara remaja dengan ibu akan dapat muncul dengan lengkap dan menyeluruh, ketika hubungan antara remaja dan ibu diliputi dengan peranan ibu, dukungan, figur, dan ikatan emosional yang kemudian secara langung maupun bersamaan mampu membentuk respek (rasa hormat) ibu dalam pandangan remaja.

\section{Pembahasan}

Hasil penelitian menemukan bagi remaja, khususnya yang ada di Provinsi Riau, ibu merupakan sosok yang amat sangat dekat dengannya. Haaasil ini juga memberikan gambaran bahwa remaja membutuhkan perasaan dekat dengan ibu. Peran ibu lebih ditekankan untuk menciptakan lingkungan yang dekat, melaui ikatan emosi (afeksi positif dan keterbukaan), peran pengasuhan, dan dukungan. Individu tidak selalu dituntut untuk mandiri dan otonom, lebih tepatnya terdapat penekanan mengenai hubungan yang saling ketergantungan (Markus \& Kitayama, 1991). Di budaya kolektif, ibu merupakan sumber dukungan sosial secara keseluruhan (Park\& Kim, 2006; Lestari, Faturochman \& Kim, 2010).Berbeda dengan barat yang individualis justru menekankan keunikan individu (individual uniquiness), keterpisahan (separateness), dan keabstrakan identitas yang menyatakan bahwa individu itu unik (Park \& Kim, 2006). Kedekatan pada budaya individual terbentuk melalui dukungan sosial yang diberikan ibu (Wagner dkk dalam Santrock, 2008). Namun, sumber dukungan sosial utama yang menyeluruh bagi remaja justru berasal dari teman sebaya, kemudian diikuti oleh ibu (O'Brien dalam Berk, 2012).

Penelitian ini menunjukkan bahwa respek merupakan alasan yang paling berperan dalam menciptakan kedekatan, jika tidak ada respek dalam hubungan antara remaja dengan ibu maka hubungan tersebut belum dapat dikatakan dekat. Montemayor (dalam Chao \& Tseng, 2002) menjelaskan bahwa respek merupakan aspek yang paling penting dalam hubungan anak dengan orang tua, bahkan dibandingkan kedekatan itu sendiri.

Berdasarkan FGD ditemukan bahwa respek ialah bentuk rasa penghargaan dan penghormatan yang telah ibu lakukan dan berikan selama rentang kehidupan remaja tersebut dan memiliki bentuk penghormatan khusus tergantung dari apa yang remaja terima dari ibunya. Terbentuk melalui segenap nilai-nilai yang ditanamkan (agama) dan melalui peranan berupa pengorbanan ibu. Terdapat sedikit keunikan dengan dibudaya asia timur lainnya. Sung (dalam Chao \& Tseng, 2002) menjelaskan menghormati orangtua dalam budaya Asia Timur sebagai suatu bentuk rasa hormat, sopan santun, harga diri, dan ketulusan, sehingga penghormatan melibatkan komponen emosional dalam membina hubungan yang harmonis dan penuh kasih sayang.

Respek dalam penelitian ini dapat tumbuh dan berkembang melalui figur dan ikatan emosional. Figur yang membentuk respek dan menciptakan kedekatan ialah figur ibu yang menginspirasi, mampu dijadikan panutan serta teladan bagi remaja sehingga ibu menjadi tokoh idaman yang sesuai dengan harapan remaja. Hurlock (1998) menjelaskan bahwa melalui figur, ibu menjalin kedekatan dengan remaja dan kemudian remaja menjadikan ibu sebagai model untuk diidentifikasikan dalam diri anak tersebut dan dibawa hingga dewasa (Hurlock, 1998).

Alasan berikutnya yang menumbuhkan respek ialah ikatan emosional. Ikatan emosional terbentuk melalui afeksi positif, keterbukaan dan diikuti kebersamaan serta perasaan dimengerti. Lestari (2013) mengungkapkan bahwa kedekatan orangtua khususnya ibu dengan anak terbentuk melalui afeksi positif, kebersamaan dalam melakukan aktivitas dan berbagi cerita (keterbukaan). Keterbukaan juga merupakan salah satu ala- 
san utama remaja dekat dengan ibu. Ditemukan keterbukaan merupakan temuan yang orisinal dibanding di wilayah lainnya, bahkan wilayah yang masih berkaitan dengan budaya kolektif seperti di Korea yang menemukan bahwa alasan utama remaja merasa dekat ialah dimengerti, nyaman dan pertalian darah (Park \& Kim, 2006). Ikatan emosional dalam penelitian ini turut dibentuk melalui dua hal yaitu dukungan dan peranan ibu.

Dukungan menjadi kategori yang menciptakan kedekatan antara remaja dengan ibunya. Park dan Kim (2006) mengungkapkan dalam budaya timur (kolektif) ibu selalu memberikan dukungan secara terus menerus sepanjang usia hidupnya. Ibu dianggap sebagai tokoh penting dalam mendukung keberhasilan anaknya (Park \& Kim 2006; Lestari, Faturochman \& Kim, 2010). Dukungan yang memberikan konstribusi dalam menciptakan kedekatan di antaranya dukungan moril, dukungan materi, inisiatif, saran, dan semangat untuk belajar.

Peranan ibu berupa pengasuhan dan pengorbanan menjadi alasan berikutnya dalam membentuk rasa dekat remaja pada ibu. Hasil FGD menjelaskan kedekatan dapat terbentuk melalui kebermaknaan berupa rasa terima kasih, keluhuran budi, hubungan langung melalui pengasuhan, rasa kasih sayang serta pengorbanan yang ibu lakukan. Chao dan Tseng (2002) mengungkapkan bahwa pengasuhan yang ibu lakukan pada budaya kolektif berorientasikan pada hubungan yang erat dan bertahan lama antara ibu dan anak. Berbeda dengan budaya individual (AmerikaEropa) pengasuhan yang ibu lakukan berorientasi pada pengembangan diri anak (Chao \& Tseng, 2002).

Menurut Putri dan Himam (dalam Hakim dkk, 2012) ibu di Indonesia menyisihkan karir profesional mereka untuk memprioritaskan perawatan untuk anaknya. Pada budaya Indonesia, pemberian perawatan antara ibu dan anak selalu mempertimbangkan tiga prinsip pengasuhan anak, yaitu asih (kasih sayang) asah (merangsang potensi) dan asuh (memenuhi kebutuhan) (Hakim dkk,2012).

Kategori berikutnya ialah pertalian darah yang mengacu pada hubungan anak dan orangtua, sebagai suatu hubungan keturunaan atau hubungan darah. Berkaitan dengan ini telah dilakukan penelitian yang dilaku- kan oleh Kim (2006)yang menunjukan bahwa di budaya Korea pertalian darah merupakan salah satu faktor utama yang menjadi alasan remaja dekat dengan ibu. Hal ini menunjukan bahwa pertalian darah merupakan hal yang berperan bagi remaja, khususnya dalam membentuk kedekatan dengan ibu. Namun terdapat perbedaan pertalian darah antara remaja dan ibu di budaya ini menjadi alasan yang sedikit berperan dalam menentukan kedekatan remaja dengan ibu.

Hasil penelitian ini turut menemukan keunikan pada remaja laki-laki yang menjadi alasan terbentuknya rasa dekat ialah karena afeksi positif sedangkan remaja perempuan ialah ketebukaan. Hal ini sejalan dengan yang disampaikan oleh Kartono (2007) mengungkapkan relasi ibu-anak laki-laki merupakan bentuk relasi yang paling komplit-lengkap dari semua bentuk relasi kemanusiaan lainnya yaitu diliputi rasa kasih sayang murni (afeksi positif), dan kalis dari emosi-emosi yang ambivalen.

Kartono (2007) menungkapkan keterbukaan yang terjadi antara ibu dengan remaja perempuan disebabkan oleh adanya rasa ingin menguasai putrinya, hal ini disebabkan sang ibu teringat dengan pengalaman-pengalamannya dimasa muda. Selanjutnya secara sadar maupun tidak, ibu berusaha agar pengalamannya (cenderung negatif) tidak terulang lagi pada anak remaja perempuannya. Dengan dalih kasih sayang, ibu senantiasa memaksa anaknya untuk melaporkan segala pengalaman hidupnya. Sehingga timbul komunikasi yang intens dan rasa diperhatikan yang dianggap sebagai manifestasi dari bentuk kasih sayang dari ibu dan membentuk ikatan secara emosional.

Penelitian ini juga menemukan bahwa remaja laki-laki lebih besar membutuhkan kehadiran ibu dalam peran berupa pengasuhan ibu (membesarkan, mengurus, merawat, membantu, mendidik, membutuhkan, dII) dan pengorbanan ibu (melahirkan, mangandung, jasa dII) sedangkan remaja perempuan lebih besar membutuhkan kehadiran ibu pada ikatan emosional, respek, dukungan, pertalian darah dan figur.

FGD juga menemukan bahwa remaja laki-laki dan perempuan memandang dan merasakan peranan ibu dalam bentuk yang berbeda. Hal ini terjadi karena remaja laki-laki 
jarang bahkan tidak sama sekali melakukan peranan seperti yang ibu lakukan (pengurusan rumah tangga dan pengasuhan). Namun pada remaja perempuan pengurusan rumah tangga, pengasuhan merupakan kegiatan sehari-hari dalam membantu ibu dirumah, sehingga remaja perempuan cenderung merasakan terbentuknya relasi secara emosional melalui peranan tersebut. Sejalan dengan penelitian yang dilakukan Seymour (dalam Chao \& Tseng, 2002) bahwa anak perempuan lebih cenderung diandalkan dalam tugas-tugas rumah tangga dibandingkan anak laki-laki.

Bhubasewar berpendapat bahwa ibu lebih mengandalkan anak perempuan dibandingkan anak laki-laki untuk memenuhi tanggung jawab yang tidak mampu mereka lakukan sendiri di rumah (dalam Chao \&Tseng, 2002). Hal yang berpengaruh lainnya ialah bahwa keterbukaan anak perempuan terhadap ibunya jauh lebih dominan dibanding anak laki-laki. Anak laki-laki lebih cenderung kurang memiliki komunikasi yang lebih intens dan terbuka pada ibunya (Barnes \& Olson, 1985). Sebagai akibat, intensitas yang tidak begitu sering dan kurangnya keterbukaan pada anak laki-laki terhadap ibunya lebih menciptakan kedekatan remaja terhadap ibu melalui hal-hal personal yang ada pada ibu seperti afeksi positif dan pengorbanan sang ibu.

Melalui konsep yang telah dipaparkan maka dapat dijelaskan bahwa ibu memiliki cara yang unik untuk menciptakan kedekatan, baik pada anak laki-laki maupun anak perempuannya yang bertujuan untuk menciptakan hubungan yang amat sangat dekat antara dirinya dengan anaknya. Chao dan Tseng (2002) menjelaskan bahwa keyakinan orangtua Asia dibentuk oleh penekanan saling ketergantungan di antara anggota keluarga dan termotivasiuntuk tujuanrelasional dalam meningkatkan kualitas serta lebih menekankan saling ketergantung dan memprioritaskan tujuandalamkelompok diatas kepentingan pribadi. Mereka menambahkan mengenai perbedaan pada budaya individualis bahwa orang-orang pada budaya tersebut lebih menekankan kemandirian dan memprioritaskan tujuan pribadi atas orang-orang dari dalam kelompok dan memiliki tujuan individu guna meningkatkan kualitas.

\section{Kesimpulan}

Remaja merasakan hubungan yang amat sangat dekat dengan ibu. faktor utama yang mempengaruhi tumbuhnya rasa dekat remaja dengan ibu disebabkan oleh adanya ikatan emosional yang terjalin antara remaja dengan ibu. Penyebab kedekatan antara remaja laki-laki dan perempuan pada ibu ialah adanya ikatan emosional, namun dalam kategori yang lebih spesifik terdapat perbedaan yang mempengaruhi ikatan emosional yang menyebabkan remaja dekat dengan ibu. Perempuan merasa dekat dengan ibu cenderung dikarenakan adanya keterbukaan (relasi), sedangkan laki-laki cenderung merasa dekat dengan ibu dikarenakan adanya hubungan emosional (person) yang berasal dari ibu.

Kedekatan akan didapatkan melalui respek (rasa hormat) terhadap ibu. Respek tumbuh melalui ikatan emosional, peranan ibu, dukungan, figur dan pertalian darah. Tanpa ada respek maka hubungan tersebut tidak dapat dikatakan sebagai hubungan yang dekat. Konsekuensi yang akan didapatkan dengan tidak terciptanya kedekatan ialah berdampak pada rendahnya respek (rasa hormat) anak terhadap ibunya.

\section{Daftar Pustaka}

Barnes, Howard L \& Olson, David H. (1985). Parent-Adolescent Commununication and the Circumplex Model. 2, Family Development and the Child: Child Development, Vol. 56, No. 2. Hal 438447. St. Paul. University of Minnesota

Chao, Ruth \& Tseng, Vivian. (2002). Parenting of Asians. Dalam Bomstein, March H (ED.2.Vol.4). Handbook of Parenting: Social Conditions and Applied Parenting. London: Lawrence Erlbaum Associates

Cicirell, Victor G. (1981). Helping Elderly Parents: The Role of Adult Children. United State: Auburn House Publishing

Driscoll, Kate \& Pianta, Robert C. (2011). Mothers' and Fathers' Perceptions of Conflict and Closeness in Parent-Child Relationships during Early Childhood. New York; University of Virginia. Journal of Early Childhood 
and Infant Psychology. Volume 72011

Feist, Jess \& Feist, Gregory J. (2011). Teory Kepribadian. Jakarta: Salemba Humanika

Feldman,S.S., Mont-Reynaud, R., and Rosenthal, D.A. (1992). When East moves West:The acculturation of values of Chinese adolescents in the U.S. and Australia. Journa lof Research on Adolescence, 2,147-173

Fuligni, A.J.,Tseng,V., and Lam, M.(1999). Attitude stowards family obligations among American adolescents with Asian, Latin American, and European backgrounds. Child Development,70,1030-1044

Hakim, M A. Thontowi, H B. Yuniarti, K W \& Kim, Uichol. (2012). The Basis of Children's Trust Towards Their Parents in Java, Ngemong: Indigenous Psychological Analysis. International Journal of Research Studies in Psychology. Volume 1 Number 2, 3-1

Hakim, M A. Supriyadi Yuniarti, K W. (2012). The Contents of Indonesian ChildParent Attachment: Indigenous and Cultural Analysis. Supplemen to Internasional Journal of Behavioral Development. Bulletin Number 2 Serial No. 62. Volume 36 Issue 6

Hurlock, Elizabeth B. (1998). Perkembangan Anak.Jakarta : Erlangga,

Hurlock, Elizabath B. (2007). Psikologi Perkembangan; suatu pendekatan sepanjang rentang kehidupan. Erlangga; Jakarta alih bahasa istiwidayanti dan soedjarwo

Hurlock, Elizabath B. (2007). Psikologi Perkembangan; suatu pendekatan sepanjang rentang kehidupan. Erlangga; Jakarta alih bahasa istiwidayanti dan soedjarwo

Hwang, K.K . (2012). Foundation of Chinese Psychology: Confucian Social Relations. Taiwan: Springer

Ihromi. T.O. (1999). Bunga Rampai; Sosiologi keluarga. Yayasan Obor Indonesia

Kartono, Kartini. (2007). Psikologi Wanita: Mengenal Wanita sebagai lbu \& Nenek. Bandung: Mandar Maju

Kim, Uichol . Yang , K S . Hwang, K K. (2006). Indigenous and Cultural Psychology:
Understanding People in Context. Taiwan : Springer

Kurniati, Ni Made Taganing. Komunikasi antara Orangtua-Anak dan Kebahagiaan. Dalam Meinaro, Eko A dan Silalahi, Karlinawati. (2010). Keluarga Indonesia: Aspek dan Dinamika Zaman. Rajawali Press: Jakarta

Lestari, Sri. (2013). Psikologi keluarga: Penanaman Nilai dan Penanganan Konflik dalam Keluarga. Jakarta: Kencana Prenada Media Group

Lestari, Sri. Faturochman \& Kim, Uicol. (2010). Trust In Parent-Child Relation Among Undergraduate Students: Indigenous Psychological Analysis. Jurnal Psikologi. Volume 37. Nomor 2. Desember 2010: 140-152

Markus, H R. Kitayama, Shinobu. (1991). Culture and The Self: Implications for Cognition, Emotion, and Motivation. Psychological Review. Vol. 98, No. 2, 224-253.University of Oregon

Noh. Che Hasniza Che \& Yusooff, Fatimah. (2011). Corak Komunikasi Keluarga dalam Kalangan Keluarga Melayu di Terengganu: (Patterns of Family Communication in Malay Families in Terengganu). Jurnal Hadhari 3 (2). Hal 45 - 62. Malaysia: Universitas Kebangsaaan Malaysia

Park, Y. S., \& Kim, U. (2006). Family, ParentChild Relationship, and Academic

Achievement in Korea: Indigenous, Cultural, and Psychological Analysis. Dalam Kim, U., Yang, K.S., \& Hwang, K.K. (Indigenous and Cultural Psychology: Understanding People in Context. Taiwan : Springer

Park, Y. S., \& Kim, U. (2010). Keluarga, Hubungan Orangtua-Anak, dan Prestasi Akademik di Korea. Dalam Kim, U., Yang, K.S., \& Hwang, K.K. (Ed.), Indigenous and Cultural Psychology Memahami Orang dalam Konteksnya. Yogyakarta: Pustaka Pelajar.

Rena Akbar, H. (2008). Psikologi Perkembangan Anak. Jakarta: Gramedia Widiasarana Indonesia (Grasindo) 
Santrock, Jhon W. (1998). Adolescence. Steinberg, Laurence. (2002). Adolescence. Erlangga: Jakarta New York: McGraw-Hill

Santrock, Jhon W. (2007). Remaja. Erlangga; Tyas, T H. Yuniarti, K W. Kim, Uichol. (2013). Jakarta

Santrock, Jhon W. (2011). Adolescent. The Role of Trust In Shaping Mother Erlangga; Jakarta

Sarwono, S.W. (2002). Psikologi Sosial. and Child Relationship: Indigenous Psychological Analysis. International Jakarta: Balai Pustaka. Journal of Research Studies In Psychology. Volume 2 Number 1, 3-12

Setiono, Kuswiratri. (2011). Psikologi Keluarga. Alumni: Bandung 